\title{
EFFECTS OF AN OIL SPILL AND DISCHARGE OF DOMESTIC SEWAGE ON THE INSECT FAUNA OF CURURU STREAM, MANAUS, AM, BRAZIL
}

\author{
COUCEIRO, S. R. M. ${ }^{1}$, FORSBERG, B. R. ${ }^{2}$, HAMADA, N. ${ }^{3}$ and FERREIRA, R. L. M. ${ }^{3}$ \\ ${ }^{1}$ Pós-graduação em Ecologia, Universidade de Brasília, Brasília, DF \\ ${ }^{2}$ Coordenação de Pesquisas em Ecologia \\ ${ }^{3}$ Coordenação de Pesquisas em Entomologia, Instituto Nacional de Pesquisas da Amazônia - INPA, \\ Avenida André Araújo, 2936, C. P. 478, CEP 69011-970, Manaus, AM \\ Correspondence to: Neusa Hamada, INPA, CPEN, Av. André Araújo, 2936, Bairro Petrópolis, C. P. 478, CEP 69011-970, \\ Manaus, AM, Brazil, e-mail: nhamada@inpa.gov.br
}

Received March 11, 2004 - Accepted October 4, 2004 - Distributed February 28, 2006

(With 8 figures)

\begin{abstract}
Assemblages of aquatic and edaphic insects in three streams in Central Amazonia were used to evaluate the impact on one of the streams (Cururu) caused by an oil spill that occurred in August 1999. The Cururu stream had already been impacted by domestic sewage. These three streams were evaluated during four different periods of the regional hydrological cycle (falling-, low-, rising- and high-water), from September 2000 to May 2001. An Eckman dredge, an aquatic entomological net and a manual auger were used to collect insects, which were used to estimate the taxonomic richness (at the family level) and insect density in each stream. Anoxic and eutrophic conditions were determined in each stream based on the mean concentration of dissolved oxygen, total nitrogen and phosphorus. Richness and abundance of insect fauna were higher in the Cristalino stream (not impacted) than in the Bom Jardim stream (impacted by domestic sewage) and in the Cururu stream, with the exception of samples collected along the stream banks (littoral fauna). The mean dissolved oxygen was lower in the Cururu stream than in the other two, while the mean concentrations of total nitrogen and phosphorus were higher. These elements showed intermediate values in the Bom Jardim stream, while the opposite pattern was observed in the Cristalino stream, with higher concentrations of dissolved oxygen and lower concentrations of total nitrogen and phosphorus. The concentrations of these variables reflect the modifications resulting from anthropogenic eutrophication caused by the discharge of domestic sewage into Bom Jardim and Cururu and by the oil spill in Cururu, which negatively affected the richness and abundance of insects in these streams.
\end{abstract}

Keywords: urban impact, sewage, oil spill, macroinvertebrates, Amazonia.

\section{RESUMO}

\section{Os efeitos de um vazamento de óleo e despejo de esgoto doméstico na fauna de insetos do igarapé Cururu, em Manaus, Amazonas, Brasil}

As assembléias de insetos aquáticos e edáficos de três igarapés da Amazônia Central foram utilizadas para avaliar o impacto sofrido por um deles (igarapé Cururu), após um vazamento de óleo derivado de petróleo, ocorrido em agosto de 1999. O igarapé Cururu já era impactado pelo despejo de esgoto doméstico. A avaliação desses sistemas foi realizada em quatro diferentes períodos do ciclo hidrológico da região (vazante, seca, enchente e cheia), entre setembro de 2000 e maio de 2001. Os insetos foram coletados com draga Eckman, rede entomológica aquática e trado, e utilizados para estimar a riqueza taxonômica (nível de família) e a densidade de insetos em cada sistema. Os efeitos de anóxia e os efeitos da eutroficação foram mensurados pelas médias de concentração de oxigênio dissolvido, nitrogênio total e fósforo total, estimadas nos três sistemas. A riqueza e abundância da fauna de insetos foram maiores no igarapé Cristalino (não 
impactado) do que nos igarapés Bom Jardim (impactado pelo despejo de esgoto) e Cururu, com exceção das amostragens de insetos litorâneos. A concentração do oxigênio dissolvido no igarapé Cururu foi menor do que nos outros dois sistemas, enquanto as concentrações de nitrogênio total e fósforo total no igarapé Cururu foram maiores. Esses elementos tiveram valores inversos no igarapé Cristalino e intermediários no igarapé Bom Jardim. As concentrações de oxigênio dissolvido, nitrogênio total e fósforo total refletem as modificações provocadas pela eutroficação antropogênica nos sistemas Bom Jardim e Cururu. Isso ocorreu devido à liberação de efluentes domésticos pelas comunidades locais e pelo óleo introduzido no igarapé Cururu, influenciando negativamente a riqueza e abundância de insetos nesses igarapés.

Palavras-chave: impacto urbano, esgoto, vazamento de óleo, macroinvertebrados, Amazônia.

\section{INTRODUCTION}

Anthropogenic disturbances in Amazonian's water bodies have caused environmental impacts that are often of unknown magnitude due to the lack of studies on these accidents. As a result, evaluations of the biological, social and economic damage caused by these accidents are difficult.

In August 1999, a submerged oil pipeline passing under the Cururu stream flowing through the city of Manaus broke, releasing petroleumderived oil into the stream. The oil quickly spread out, covering the submerged vegetation and the sediments along the banks of the stream with a thick layer of residue. Part of the oil floating on the water's surface was recovered by Refinaria de Manaus (REMAN)/PETROBRAS and the rest sank, covering the benthic zone of the system.

Like other black-water streams in the region, the Cururu stream is a nutrient-poor system (Sioli, 1956) that depends on allocthonous material for its maintenance and enrichment (Junk, 1997). The presence of herbaceous macrophytes in the Cururu stream is atypical for black water systems (Junk \& Piedade, 1997), indicating that this stream is also undergoing eutrophication caused by domestic sewage dumped into it by the local community. Only $3 \%$ of the sewage produced in Manaus is treated (Projeto Geo Cidades, 2002) and part of it is dumped directly into streams despite awareness of its effect on the aquatic community (Mellanby, 1982). Little is known about the effects of organic enrichment of water courses in the Amazonian region (Cleto-Filho \& Walker, 2001).
The macroinvertebrate fauna, especially aquatic insects, have been used in biological monitoring programs because they can reflect environmental modifications (McCafferty, 1983; Alba-Tercedor \& Sánchez-Ortega, 1988; Thorp \& Covich, 1991; Alba-Tercedor, 1996). Changes in community structures caused by environmental perturbation can be manifested by extinction, reduction or increment of populations, depending on the tolerance of each species (Spies \& DesMarais, 1983). The chemical and organic modifications caused by pollutants in stream waters affect not only the aquatic biota (Branco, 1972; Lytle \& Perckarsky, 2001) but also the local human population that uses these streams for recreational activities, especially for swimming and fishing.

The objective of the present study is to evaluate the effect of a petroleum-derived oil spill and of domestic sewage on the Cururu stream insect assemblage, taking into consideration the natural dynamics of this water course.

\section{MATERIALS AND METHODS}

\section{Study area}

To evaluate the impact of the oil spill and domestic sewage on the insect fauna of the Cururu stream $\left(03^{\circ} 07^{\prime} 69^{\prime \prime} \mathrm{S}\right.$; 59 56 $59^{\prime}$ " W) we used two controls: the Bom Jardim stream (0307' 69” S; 59 56' 54” W), which is impacted by urban sewage; and Cristalino stream $\left(03^{\circ} 08^{\prime} 42^{\prime \prime} \mathrm{S} ; 60^{\circ} 08^{\prime} 51^{\prime \prime} \mathrm{W}\right)$, with no impact (Fig. 1). These systems are tributaries of 
the Rio Negro and are therefore affected by the inundation pulse. The region's hydrological cycle can be divided into four periods: high-, falling-, low- and rising-water. In the rising and high-water periods, this stream is dammed by the waters of the Rio Negro, becoming part of the inundated forest, or Igapó, of this large river. Junk et al. (1989) found that the "Pulse of Inundation" is the main factor controlling the structure and dynamics of the biological communities associated with these river systems in Amazonia.

\section{Methods}

Fieldwork was done in four periods of the hydrological cycle (high-, falling-, low- and risingwater periods), from September 2000 to May 2001
(Fig. 2). Three transects (from one bank to the other) were marked out in each stream. Ten sampling sites were defined in each transect (Fig. 3). At each site, samples of the edaphic insect fauna were taken with a manual auger $\left(158 \mathrm{~cm}^{2}\right)$, benthic insect fauna were collected with an Eckman dredge $\left(232 \mathrm{~cm}^{2}\right)$, and littoral insect fauna were collected with an aquatic D-net $\left(294 \mathrm{~cm}^{2}\right)$ from the submerged litter on the banks of the stream.

In the laboratory, the edaphic insect fauna was extracted from the litter/soil using the Berlese method. During the extraction period the specimens were maintained in liquid formaldehyde (1\%), and later they were washed and preserved in $80 \%$ ethanol. The littoral and benthic samples were washed through a $1 \mathrm{~mm}$ mesh sieve and

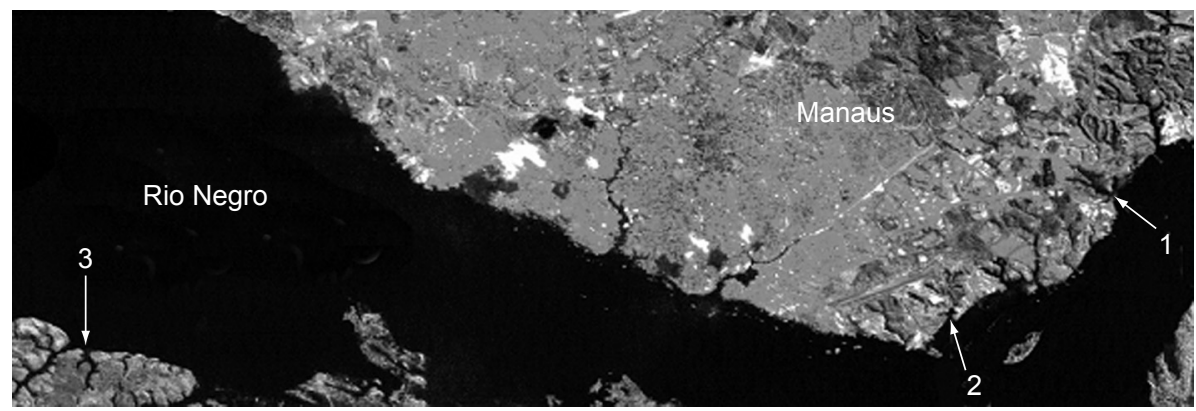

Fig. 1 - LandSat image showing the study sites: 1) Cururu stream; 2) Bom Jardim stream; and 3) Cristalino stream, Manaus, state of Amazonas, Brazil.

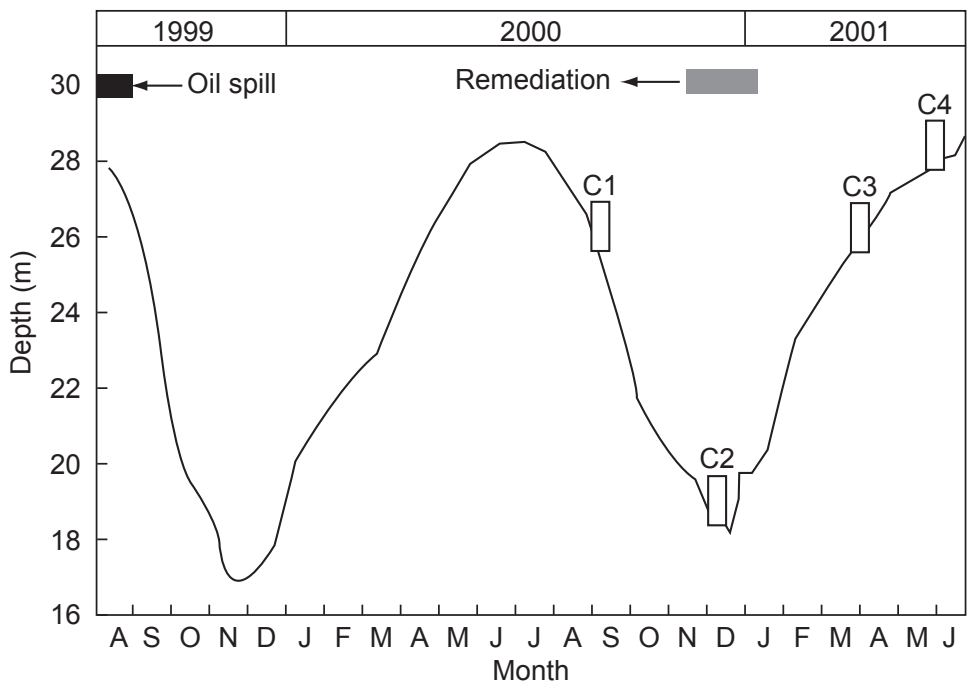

Fig. 2 - Water level of the Rio Negro, indicating the time of the oil spill, remedial action and sampling in the different phases of the hydrological cycle: C1) falling-water period; C2) low-water period; C3) rising-water period; and C4) high-water period (C4). 


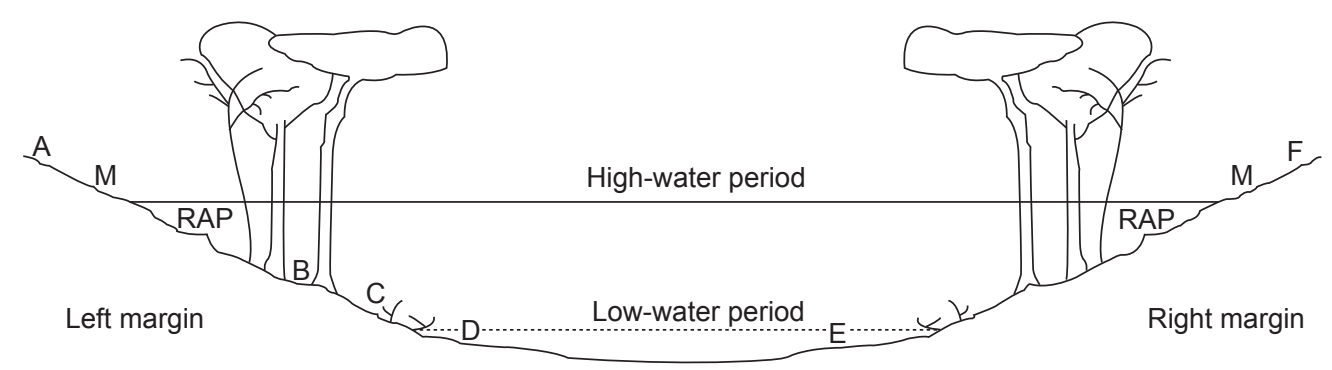

Fig. 3 - Representation of one transect, indicating the sampling sites. The points labeled " $\mathrm{M}$ " are the locations of auger sampling $0.5 \mathrm{~m}$ from the water line; "A" and "F" are auger sampling locations above the water level; "B", "C", "D" and "E" are auger sampling locations (low-water period) or dredge sampling (high-water); points marked "RAP" are D-net sampling locations in the submerged litter.

the specimens were preserved in $80 \%$ ethanol. Identification of the specimens was done under a dissecting microscope.

Taxonomic richness (family level) and density of insects were determined for each collection site and associated with the site's inundation period. Each stream was chemically characterized based on the following parameters: total nitrogen (TN) and total phosphorus (TP) $(\mu \mathrm{M})$ in samples from the water's surface analyzed using Valderrama (1981) methodology, and dissolved oxygen $\left(\mathrm{O}_{2}\right)$ $(\mathrm{mg} / \mathrm{L})$ (YSI 55 oxymeter) measured at the watersediment interface. The effects of anoxia on the abundance and richness of benthic insect fauna and the differences among the studied systems were analyzed by regression analysis. The specific effects of urban eutrophication on the concentration of total nutrients were evaluated using the mean values of total nitrogen and total phosphorus.

\section{RESULTS}

The richness and abundance of aquatic insects in the non-impacted Cristalino stream were, in general, higher than in the impacted streams (Bom Jardim and Cururu) (Figs. 4a-c, 4e-f, ANOVA, $\mathrm{P}<0.001)$. The exception was littoral aquatic insects, for which abundances did not differ significantly among the sampled streams (Fig. 4d, ANOVA, $\mathrm{P}>0.05$ ).

The insect richness at the family level and the abundance varied significantly from one stream to another and among the periods of the hydrological cycle (Figs. 5a-f). The differences in mean dissolved $\mathrm{O}_{2}$ concentrations in the sampled streams were also significant (Figs. 6a-b, ANOVA, $\mathrm{P}<0.001$ ). The dissolved $\mathrm{O}_{2}$ concentration was higher in the
Cristalino stream than in the Bom Jardim and Cururu streams (Fig. 6a). The highest concentration of dissolved $\mathrm{O}_{2}$ occurred in the low- and risingwater periods, while the lowest concentrations of dissolved $\mathrm{O}_{2}$ in all the systems studied were found in the falling- and high-water periods (Fig. 6b). Total nitrogen and total phosphorus concentrations were the highest in the Cururu stream (Table 1).

\section{DISCUSSION}

The lowest richness and abundance of benthic insect fauna in the Cururu stream was observed in the falling-water period at the beginning of this study, possibly as a result of the high oil concentration in the benthic zone of this stream after the oil spill. Reduced aquatic macroinvertebrate richness and abundance were observed by Shimizu et al. (1995) in the Alambari River five months after an oil spill.

The increase in richness and the peak of abundance during the low-water period in the Cururu stream were surprising considering the intensive remediation operation carried out by REMAN/Petrobrás at the time, which included dredging of a large amount of sediments from the benthic zone. However, the abundance of insects in the Cururu stream in the low-water period was strongly affected by three exceptionally high values considered "outliers". In all periods of the year, the mean abundance of insects in the Cururu stream was near zero and similar to or much lower than the abundances found in the other two streams (Fig. 5b). Considering only the falling-, rising- and high-water periods, the abundance in the Cururu stream was significantly lower than in the other two streams. 

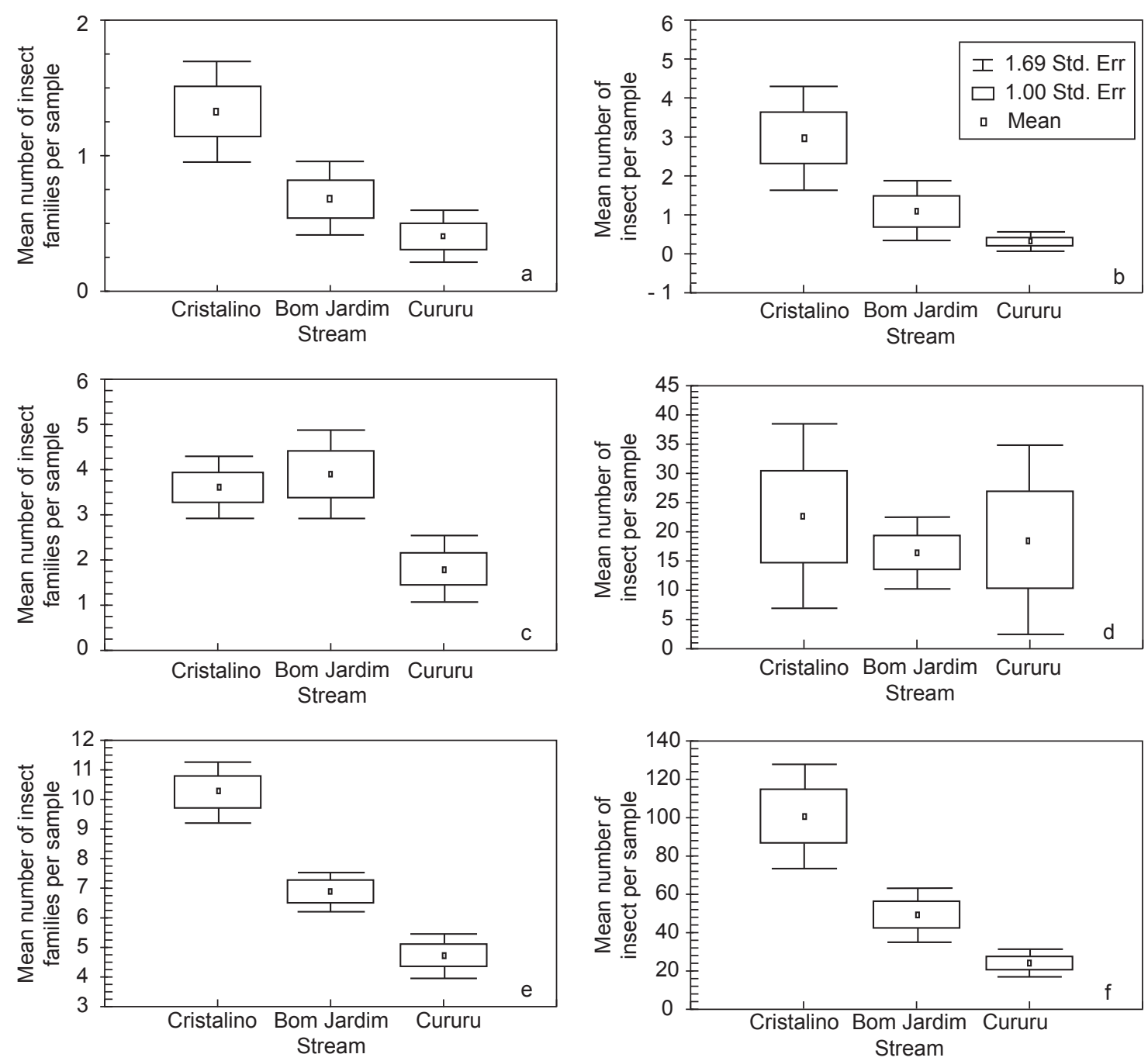

Fig. 4 - a,b) Mean values of the family-level richness and the abundance of benthic insects; c,d) littoral insects; and e,f) edaphic insects, in the three streams (Cristalino, Bom Jardim and Cururu), in Manaus, Amazonas, Brazil (September 2000 - May 2001).

TABLE 1

Mean concentrations ( $\mu$ moles/liter) of total Phosphorus (TP) and Nitrogen (TN) in three streams in the municipality of Manaus, state of Amazonas, Brazil (Sept 2000 - May 2001).

\begin{tabular}{|l|c|c|}
\hline \multicolumn{1}{|c|}{ Stream } & TP & TN \\
\hline Cristalino & 0.35 & 38.46 \\
\hline Bom Jardim & 0.87 & 36.42 \\
\hline Cururu & 2.97 & 59.70 \\
\hline
\end{tabular}

One of the factors that most influences the richness of benthic fauna is the concentration of dissolved $\mathrm{O}_{2}$ at the sediment-water interface. This is because few organisms can survive in this zone where dissolved $\mathrm{O}_{2}$ concentration approaches zero (Junk \& Robertson, 1997; Wang et al., 2001).

Seasonal variations in dissolved $\mathrm{O}_{2}$ levels are related to variations in the depth of the water column 

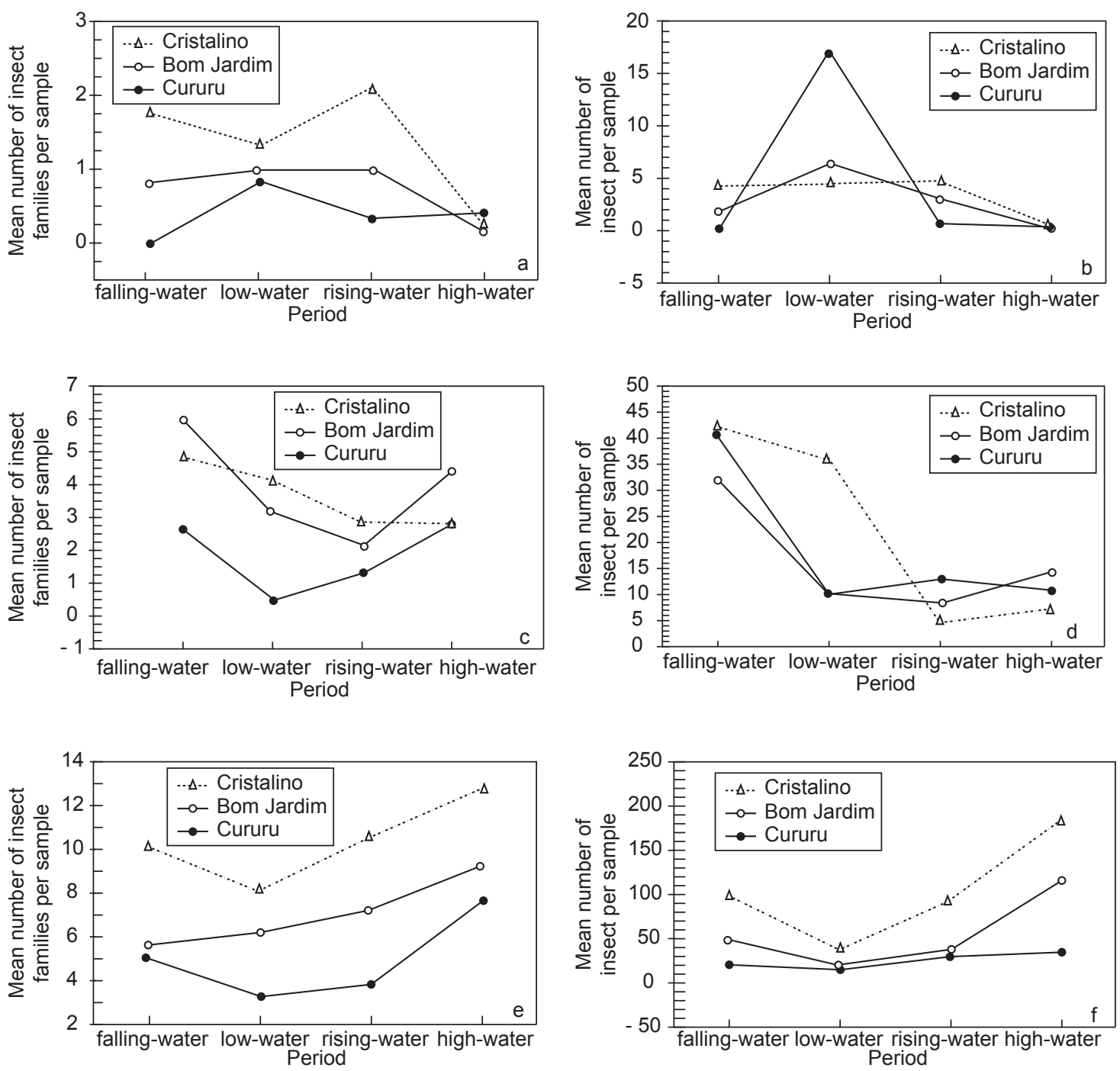

Fig. 5 - a,b) Mean values of family-level richness and abundance of benthic insect; c,d) littoral insects; and e,f) edaphic insects in the three streams (Cristalino, Bom Jardim and Cururu) during the different periods of the hydrological cycle, in Manaus, Amazonas, Brazil (September 2000 - May 2001).

(Tundisi et al., 1984). This is easily ascertained by plotting the dissolved $\mathrm{O}_{2}$ concentration values at the sediment-water interface of the three streams against the depth of the water column, which reveals a strong inverse relationship (Fig. 7). However, the mean dissolved $\mathrm{O}_{2}$ concentration at the sediment-water interface varied among the streams (Figs. 6a-b), probably due to differences in the biological oxygen demand (BOD) or chemical oxygen demand (COD) of the studied streams. These factors are related to different levels of eutrophication, as indicated by the total nitrogen and total phosphorus concentrations. These are the nutrients that are most frequently associated with anthropogenic eutrophication (Vollenweider, 1969). For Amazonian aquatic ecosystems, low nitrogen and phosphorus concentrations are factors that limit primary productivity (Forsberg, 1984; Setaro \& Melack, 1984; Melack \& Forsberg, 2001). Therefore, both nutrients are probably of anthropogenic origin in the Cururu stream. Increased eutrophication is generally followed by an elevation of the BOD and a lowering of the dissolved $\mathrm{O}_{2}$ concentration. As 

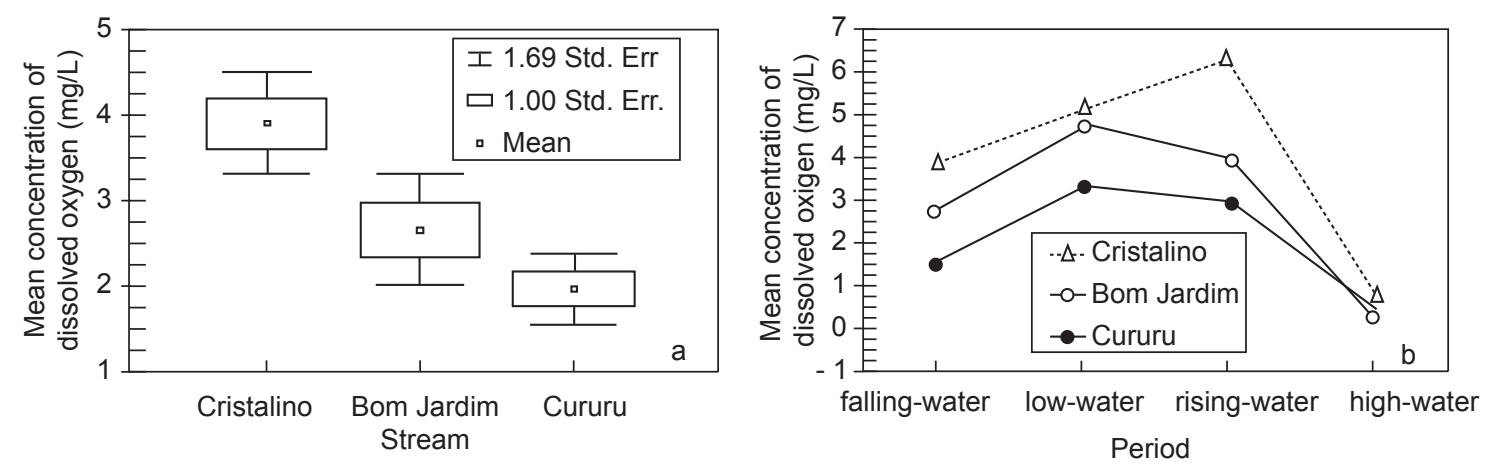

Fig. 6 - Mean concentrations of dissolved oxygen $(\mathrm{mg} / \mathrm{L})$ at the water-sediment interface in the three streams (Cristalino, Bom Jardim and Cururu) (a), in the different periods of the hydrological cycle (b), in Manaus, Amazonas, Brazil (September 2000 - May 2001).

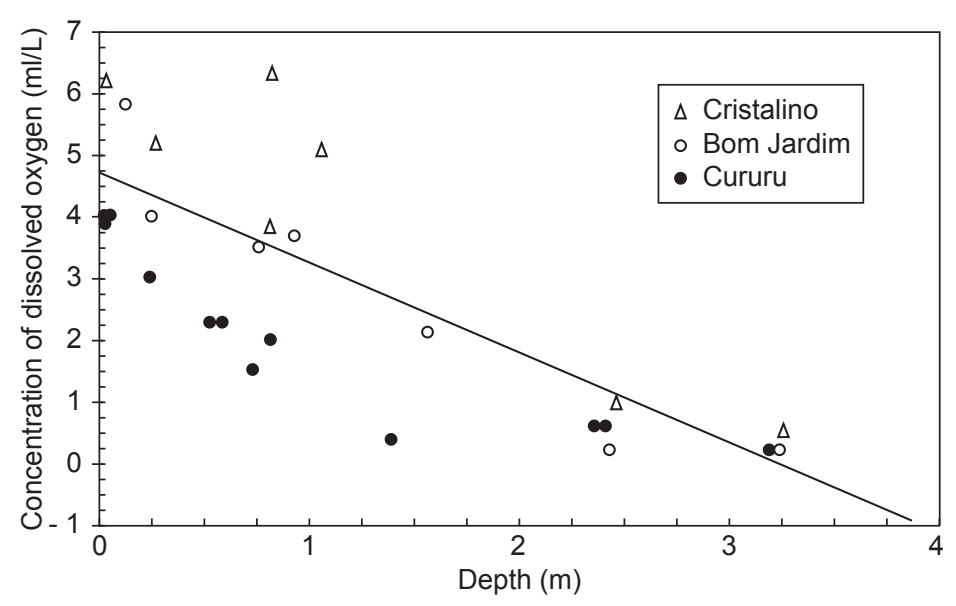

Fig. 7 - Relation between dissolved oxygen concentrations at the water-sediment interface and depth of the water column in the three streams (Cristalino, Bom Jardim and Cururu) in Manaus, Amazonas, Brazil (September 2000 - May 2001).

a result, much of the variation in the dissolved $\mathrm{O}_{2}$ concentration observed among the streams can be attributed to the different levels of eutrophication. The low values of dissolved $\mathrm{O}_{2}$ concentration in Cururu may also be a consequence of the additional impact caused by the oil spill, which probably increased the BOD and COD, especially near the sediment-water interface where the oil accumulated. Figs. $8 \mathrm{a}$ and $8 \mathrm{~b}$ clearly illustrate the relation of the dissolved $\mathrm{O}_{2}$ concentration with family-level richness and abundance of the benthic insect fauna, showing a strong positive correlation (nonlinear regression, $\mathrm{p}<0.01$ ) between these two factors, with the highest dissolved $\mathrm{O}_{2}$ concentration and benthic insect fauna richness and abundance occurring in the Cristalino stream and the lowest in the Cururu stream. An overall analysis of all the data collected from the three streams reveals a significant positive relationship between the dissolved $\mathrm{O}_{2}$ concentration at the sediment-water interface and the benthic insect fauna. With the exception of three anomalous values in the Cururu and one in the Bom Jardim stream, the dissolved $\mathrm{O}_{2}$ concentration levels and benthic insect fauna abundance were lower in the Cururu and higher in the Cristalino streams, with intermediate values in the Bom Jardim stream.

Samples collected with the auger at the edges of transects contained mainly edaphic insects. The differences in richness among the three streams in question are probably associated with the quality of the soil of each system, which reflects the state of eutrophication of each site (Table 1). The lowest richness and abundance were observed in the Cururu 

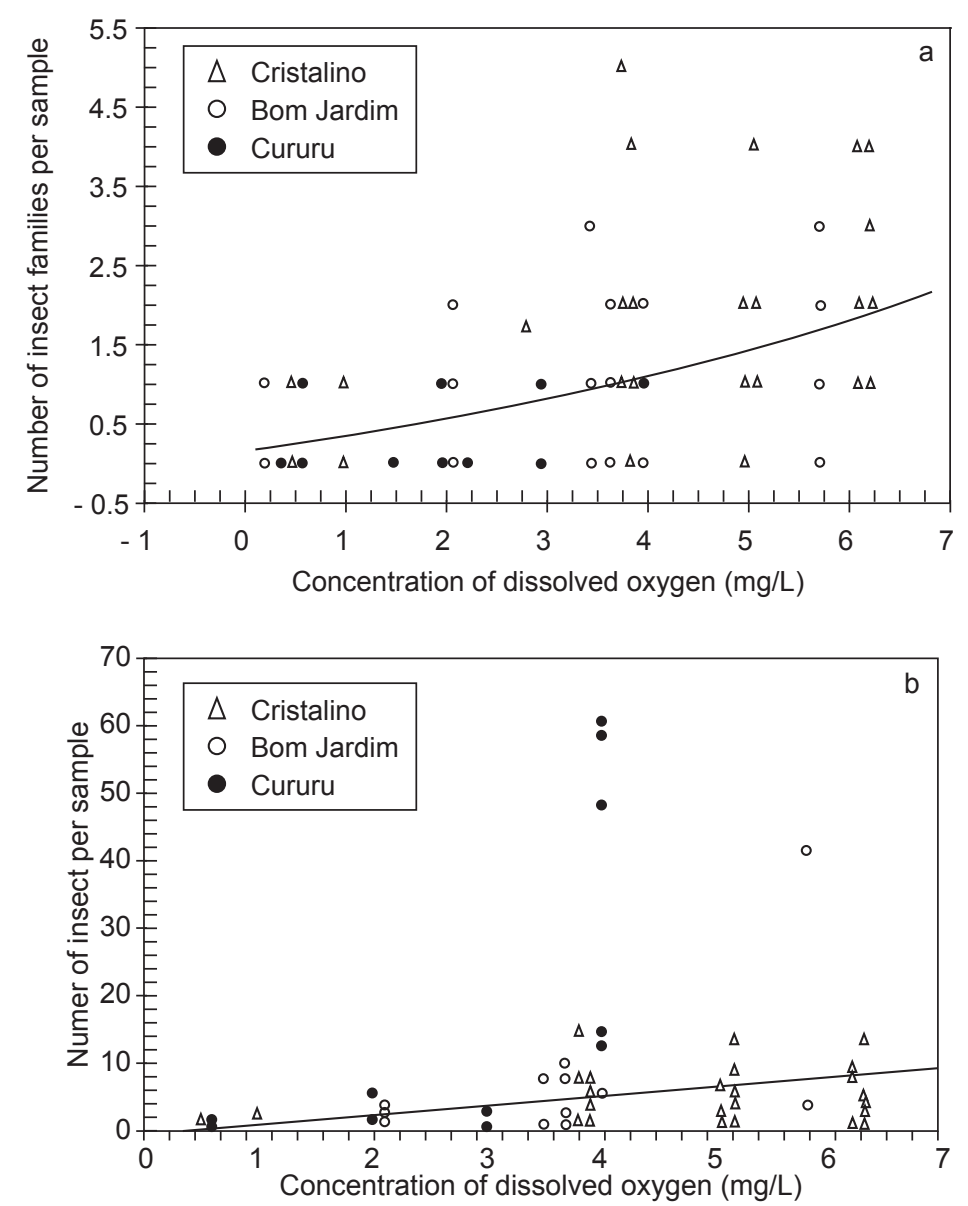

Fig. 8 - a) Relation between the mean concentration of dissolved oxygen at the water-sediment interface and family-level richness; and b) abundance of benthic insects in the streams (Cristalino, Bom Jardim and Cururu) in Manaus, Amazonas, Brazil (September 2000-May 2001).

stream, possibly resulting from the influence of oil residues and domestic sewage incorporated into the soil, affecting the toxicity or limiting $\mathrm{O}_{2}$ diffusion at the soil-atmosphere interface.

In the low-water period, the edaphic insect fauna had the lowest richness and abundance, while the highest values occurred in the high-water period. These results findings may have been a consequence of variations in soil humidity, which is a key factor in insect community development (Adis, 1997; Adis \& Junk, 2002). Soil humidity is generally lowest at the end of the dry season (lowwater period) and highest at the end of the rainy season (high-water period).
The auger and dredge samples were always collected from the same predefined topographic points along each transect. The different topographic levels corresponded to the different periods of inundation, which are key characteristics of the inundation pulse process that affects the distribution and dynamics of biota of large rivers in the Amazonian region. In any given inundation period, richness and abundance of edaphic and benthic insect fauna were lowest in Cururu, highest in Cristalino and intermediate in Bom Jardim. In addition to the differences in the trophic state of these streams, the low levels of richness and abundance in the Cururu stream may also be a reflection of additional direct and indirect 
effects of oil contamination, since toxic substances can eliminate sensitive organisms in aquatic ecosystems (Branco, 1972; Spies \& DesMarais, 1983; Groenendijk et al., 2002).

The samples collected with D-nets along the banks of the streams consisted mostly of benthic insects and insects associated with tree roots from the stream banks or submerged vegetation. The highest richness and abundance values for littoral insect fauna were observed in the falling-water period, apparently reflecting the better conditions for this community's growth in this period. The lowest level of richness in the Cururu stream in most of the periods (Fig. 5c) may reflect the direct effect (toxicity) or indirect effects (e.g., decrease of $\mathrm{O}_{2}$ diffusion) of oil contamination. The trend, in this case, can be attributed to the eutrophication process, since the levels of richness in the Bom Jardim and Cururu streams were similar.

The abundance and richness of benthic insect fauna in Cururu were lower than in the undisturbed stream (Cristalino) due to the low dissolved $\mathrm{O}_{2}$ concentration at the sediment-water interface resulting from high $\mathrm{BOD}$ and $\mathrm{COD}$ in the water column. High BOD and COD, in turn, result from the system's anthropogenic eutrophication due to the discharge of domestic effluents by the local community (Cleto-Filho \& Walker, 2001) and the oil introduced into the stream by the spill.

The levels of abundance and richness of the edaphic insect fauna in the Cururu were low compared to those of the undisturbed stream (Cristalino), probably due to the soil characteristics associated with eutrophication and to the direct (toxicity) and indirect effects (decrease in $\mathrm{O}_{2}$ diffusion) associated with soil contamination by oil residues.

Acknowledgments - S. R. M. Couceiro is indebted to CNPq/ PIBIC/INPA for a fellowship. The authors acknowledge the financial support of this work by REMAN/PETROBRAS, MCT/INPA/PPI 1-3630, MCT/CNPq and CNPq/CT-Petro (460993/00-3). Thanks are also due to Ulysses Carvalho Barbosa, Jéferson Oliveira da Silva and João Rocha for their help with the field work. This manuscript was reviewed by Philip M. Fearnside and proofread by Beatrice Allain.

\section{REFERENCES}

ADIS, J. \& JUNK, W. J., 2002, Terrestrial invertebrates inhabiting lowland river floodplains of Central Europe a review. Freshwater Biol., 47: 711-731.
ADIS, J., 1997, Terrestrial invertebrates: survival strategies, group spectrum, dominance and activity patterns, pp. 299-317. In: Junk, W. J. (ed). The Central Amazon Floodplain. Ecological Studies 126. Springer, Berlin. $525 \mathrm{p}$.

ALBA-TERCEDOR, J., 1996, Macroinvertebrados acuáticos y calidad de las aguas de los ríos. SIMPOSIO DEL AGUA IN ANDALUCÍA (SIAGA), 4. Almeria., 2: 203-213.

ALBA-TERCEDOR, J. \& SÁNCHEZ-ORTEGA, A., 1988, Un método rápido y simples para evaluar la calidad biológica de las aguas corrientes basada en el de Hellawell (1978). Limnética., 4: 51-56.

BRANCO, S. M., 1972, Poluição: A morte de nossos rios. Ao livro técnico, Rio de Janeiro, 157p.

CLETO-FILHO, S. E. N. \& WALKER, I., 2001, Efeitos da ocupação urbana sobre a macrofauna de invertebrados aquáticos de um igarapé da cidade de Manaus/AM - Amazônia Central. Acta Amazonica, 31(1): 69-89.

FORSBERG, B. R., 1984, Nutrient processing in Amazon floodplain lakes. Int. Ver. Theor. Angew. Limnol. Verh., 22: 1294-1298.

GROENENDIJK, D., LÜCKER, S. M. G., PLANS, M., KRAAK, M. H. S. \& ADMIRAAL, W., 2002, Dynamics of metal adaptation in riverine chironomids. Environ. Pollut., 117: 101-109.

JUNK, W. J., 1997, General aspects of floodplain ecology with special reference to Amazonian floodplains. The Central Amazon Floodplain, pp. 3-20. In: Junk, W. J. (ed.) The Central Amazon Floodplain. Ecological Studies 126. Springer, Berlin, 525p.

JUNK, W. J., BAYLEY, P. B. \& SPARKS, R. E., 1989, The flood pulse concept in river floodplain systems. In: Dodge, D. P. (ed.) Proc. International Large River Symposium (LARS). Can. Spec. Publ. Fish. Aquat. Sci., 106: 110-127.

JUNK, W. J. \& PIEDADE, M. T., 1997, Plant life in the floodplain with special reference to herbaceous plants, pp. 147-187. In: W. J., Junk (ed.) The Central Amazon Floodplain. Ecological Studies 126. Springer, Berlin, $525 \mathrm{p}$.

JUNK, W. J. \& ROBERTSON, B.A., 1997, Aquatic invertebrates, pp. 279-298. In: W. J., Junk (ed.). The Central Amazon floodplain. Ecological Studies 126. Springer, Berlin, 525p.

LYTLE, D. A. \& PERCKARSKY, B. L., 2001, Spatial and temporal impacts of a diesel fuel spill on stream invertebrates. Freshwater Biol., 43(5): 693-704.

MCCAFFERTY, W. P., 1983, Aquatic Entomology. Jones and Bartlett Publishers, Inc., Boston, MA, 448p.

MELACK, J. \& FORSBERG, B. R., 2001, Biogeochemistry of Amazon floodplain lakes, pp. 235-276. In: M. E., Mcclain, R., victoria and J. E., Richey (eds.). The Biogeochemistry of the Amazon Basin and its Role in a Changing World. Oxford University Press, New York.

MELlANBY, K., 1982, Biologia da Poluição. (tradução de Lúcia Baungartner Lamberti). São Paulo. EPU. Temas de Biologia 28:89p.

Projeto Geo-Cidades: Relatório Urbano Ambiental Integrado: Informe Geo: Manaus, 2002, Supervisão: Ana Lucia 
Nadalutti La Roven, Samyra Crespo; coordenação: Rui Velloso. Rio de Janeiro: Consórcio Parceria 21, 188p.

SETARO, F. V. \& MELACK, J. M., 1984, Responses of phytoplankton to experimental nutrient enrichment in an Amazon Lake. Limnol. Oceanogr., 28: 972-984.

SHIMIZU, G. Y., GARCIA, E., EYSINK, G. G. J., COHENCA, D., ANAYA, M. \& TAKEDA, A. M., 1995, Avaliação biológica do derramamento de petróleo no rio Alambari, bacia do rio Paraíba do Sul, São Paulo, Brasil. SIMPÓSIO BRASILEIRO DE RECURSOS HÍDRICOS/E/SIMPÓSIO DE HIDRÁULICA E RECURSOS HÍDRICOS DE PAÍSES SE LÍNGUA OFICIAL PORTUGUESA II, 11. Proceedings...Recife: ABRH publicações, 3: 213-217.

SIOLI, H., 1956, Umber Natur and Mensh in brasilianinchen Amazonas gebiet. Erdkunde, 10: 89-109.

SPIES, R. B. \& DESMARAIS, D. J., 1983, Natural isotope study of trophic enrichment of marine benthic communities by petroleum seepage. Mar. Biol., 73: 67-71.
THORP, J. H. \& COVICH, A. P., 1991, Ecology and Classification of North American Freshwater Invertebrates. Academic Press Inc., New York, 911p.

TUNDISI, J. G., FORSBERG, B. R., DEVOL, A. H., ZARET, T. M., TUNDISI, T. M., DOS SANTOS, A., RIBEIRO, J. S. \& HARDY, E., 1984, Mixing patterns in Amazon Lakes. Hydrobiol., 108: 3-15.

VALDERRAMA, J. C., 1981, The simultaneous analysis of total nitrogen and total phosphorus in natural waters. Mar. Chem., 10: 109-122.

VOLLENWEIDER, R. A., 1969, Moglichkeiten und Grenzen elementar Modelle de Stoffbilanz von Seen. Arch. Hydrobiol., 66: 1-36.

WANG, F., TESSIER, A. \& HARE, L., 2001, Oxygen measurements in the burrows of freshwater insects. Freshwater Biol., 46: 317-327. 